\title{
Achatina fulica (Gastropoda: Pulmonata): Occurrence, environmental aspects and presence of nematodes in Sergipe, Brazil
}

\author{
G. M. Silva ${ }^{a *}$ (D), M. B. Santos ${ }^{b}$ (D), C. M. Melo ${ }^{a}$ (D) and V. L. S Jeraldo ${ }^{a}$ \\ ${ }^{a}$ Universidade Tiradentes - UNIT, Instituto de Tecnologia e Pesquisa - ITP, Laboratório de Doenças Infecciosas e \\ Parasitárias - LDIP, Av. Murilo Dantas, 300, Prédio do ITP, Bairro Farolândia, CEP 49032-490, Aracaju, SE, Brasil

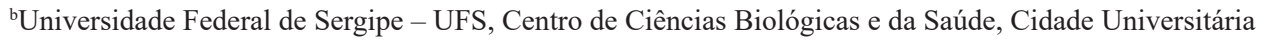 \\ Prof. José Aloísio de Campos, Jardim Rosa Elze, CEP 49100-000, São Cristovão, SE, Brasil \\ *e-mail: guilhermemota.enf@gmail.com
}

Received: January 17, 2018 - Accepted: November 1, 2018 - Distributed: May 31, 2020

(With 5 figures)

\begin{abstract}
The objective of this study was to identify the occurrence of Achatina fulica in the Great Aracaju-SE Territory. This research was developed during the months of June 2016 to May 2017. The plots methodology was used for the monthly collections, following the collection time of 20 minutes per area. The mollusks were measured and soon afterwards the parasitological analysis of the mucus and faeces was performed. Molecular identification was performed to evaluate the possible presence of Angiostrongylus sp. We observed that the occurrence of A. fulica was more representative in urban areas, especially in vacant lots with the presence of litter and decomposing materials. In the specimens of A. fulica examined were male and female nematodes of the genus Rhabditis, in the research municipalities, except in Barra dos Coqueiros. No parasites of the genus Angiostrongylus were found in the mollusks examined. The influence of the presence of litter on the plots associated with the frequency of A. fulica was statistically significant. There was a correlation between the influence of rainfall and the frequency of $A$. fulica. A significant relationship between moisture and frequency and nematode positivity was identified. It was also observed that the larger the mollusk, the greater the chances of being infected by nematodes. Scientific knowledge about the biology of the A. fulica species associated with human intervention such as the maintenance of land and adequate sanitary measures may be important factors for a better control of this invasive mollusk.
\end{abstract}

Keywords: Achatina fulica, nematode infection, seasonality.

\section{Achatina fulica (Gastropoda: Pulmonata): ocorrencia, aspectos ambientais e presença de nematódeos em Sergipe, Brasil}

\section{Resumo}

O objetivo deste estudo foi verificar a ocorrência de $A$. fulica no território da Grande Aracaju, Sergipe, avaliando a infecção destes moluscos por nematódeos, a influência das condições climáticas e das características do ambiente. Esta pesquisa foi desenvolvida durante os meses de junho de 2016 a maio de 2017. Foi utilizada a metodologia de parcelas para as coletas mensais de 20 min por área, um total de 15 parcelas distribuídas em 5 municípios. Os moluscos foram mensurados e logo em seguida realizada a análise parasitológica do muco e fezes. Foi realizada a identificação molecular para avaliar a possível presença de Angiostrongylus sp. Observamos que a ocorrência de $A$. fulica foi mais representativa em áreas urbanas, sobretudo em terrenos baldios com a presença de lixo e materiais em decomposição. Nos exemplares de A. fulica examinados foram encontrados nematódeos do gênero Rhabditis, nos municípios da pesquisa, exceto em Barra dos Coqueiros. Não foram encontrados parasitos do gênero Angiostrongylus nos moluscos examinados. A influência da presença de lixo nas parcelas associado à frequência da $\mathrm{A}$. fulica mostrou-se estatisticamente significativa. Houve correlação entre a influência da chuva e a frequência de $A$. fulica. Foi identificada uma relação significativa entre a umidade e a frequência e a positividade para nematódeos. Foi também observado que quanto maior o molusco, maiores são as chances deste apresentar nematódeos. O conhecimento científico a respeito da biologia da espécie $A$. fulica associado à intervenção humana como, a manutenção de terrenos e medidas sanitárias adequadas podem ser fatores importantes para um controle malacológico mais adequado para esta espécie invasora.

Palavras-chave: Achatina fulica, infecção por nematódeos, sazonalidade. 


\section{Introduction}

The Achatina fulica Bowdich 1822 gastropod, is a natural mollusks of African ecosystems, currently distributed on almost all continents (Africa, the Americas, East and South Asia and Oceania). The African giant mollusk, as it is known, is considered an invasive species outside its continent of origin, being a threat to public health, natural biodiversity and agriculture (Thiengo et al., 2007; Colley, 2010; Zanol et al., 2010; Sarma et al., 2015). In Brazil, its introduction apparently occurred in 1988 in an agricultural market in the state of Paraná as an alternative to consumption of Helix aspersa (Muller, 1774) (Fischer et al., 2006).

Nowadays $A$. fulica has been reported in the most diverse environments such as forests, capoeiras, caatingas, savannahs, plantations, vegetable gardens, decomposing materials and urban areas (Eston et al., 2006; Ohlweiler et al., 2010; Santos, Delabie, 2011; Onyshi et al., 2018). Recently, infestation has been reported in urban areas of the Brazilian Amazon, probably due to transport of the mollusks in accidental loads; this is a matter of concern for the dispersal capacity and lack of natural mollusk predators (Moreira et al., 2013; Lima and Guilherme, 2018). The soil plays a key role in the protection of A. fulica, since it is used as a food source and defense strategy (Fischer et al., 2010). Of the 26 Brazilian states, A. fulica has been recorded in 25 of them (Caldeira et al., 2007; Thiengo et al., 2013).

The Brazilian states with the highest rates of infestation by $A$. fulica are: Goiás, São Paulo, Paraná, Rio de Janeiro, Mato Grosso, Espírito Santo and Minas Gerais) (Ohlweiler et al., 2010; Zanol et al., 2010). In the Northeast region at the state of Bahia, there are records of the presence of A. fulica in Salvador, Canavieiras, Caravelas, Itaparica, Ilhéus, Eunápolis, Lauro de Freitas and Porto Seguro (Silva and Aleluia, 2010; Santos and Delabie, 2011). In the state of Sergipe there are records of the presence of the giant African mollusk at the cities of Itaporanga d'Ajuda, Estância, Boquim, Areia Branca, Capela, Siriri, Aracaju and Lagarto (Oliveira et al., 2007; Thiengo et al., 2008).
The A. fulica mollusk may be host to several species of nematodes, in Brazil there are records of mollusks naturally infected with larvae of Aelurostrongylus abstrusus, Rhabditis sp., Strongyluris sp. and Angiostrongylus cantonensis. Besides of being host to these parasites, A. fulica may be an intermediate host of Angiostrongylus costaricensis and Angiostrongylus vasorum, and there is no record of the natural transmission in Brazil of these two species (Wang et al., 2008; Graeff-Teixeira et al., 2009; Oliveira et al., 2010; Almeida, 2013; Moreira et al., 2013). In Colombia, at the cities of Cartago, Cali and Boaventura have been identified mollusks $A$. fulica infected with larvae of Strongyluris sp., A. cantonensis and A. abstrusus (Córdoba-R et al., 2017).

In the urban environmental scenario, A. fulica is found in humid environments and in direct contact with garbage and sewage (Zanol et al., 2010; Boaventura et al., 2011). The disorganized urban growth, precarious basic sanitation, unfinished constructions, and irregular garbage collection favor the maintenance and proliferation of A. fulica (Ohlweiler et al., 2010).

Therefore the objective of this study was to verify the occurrence of A. fulica in the Great Aracaju, Sergipe, evaluating the infection of these mollusks by nematodes, the influence of the climate conditions and environmental characteristics.

\section{Material and Methods}

\subsection{Area of study, collection and identification of mollusks}

The study area is corresponded to the territory of the great Aracaju, formed by five cities whose territorial and climatic characteristics are presented in Table 1. The choice of the neighborhood was made based on complaints made by the community and community health agents. In each neighborhood, three parcels with a size of $20 \times 10 \mathrm{~m}$ totaling 15 study areas were delimited.

At the period between June 2016 to May 2017, monthly collections of $A$. fulica were carried out in each city, with standardization of sampling effort: daytime manual collection performed by two collectors (sample effort unit $=20 \mathrm{~min} /$ collector ). After each collection, the

Table 1. Socio-environmental data of the municipalities in the Great Aracaju Territory, Sergipe, Brazil.

\begin{tabular}{lccccc}
\hline \multicolumn{1}{c}{ Municipalities } & Area $\left(\mathbf{K m}^{2}\right)$ & $\begin{array}{c}\text { Population* } \\
\text { (hab) }\end{array}$ & $\begin{array}{c}\text { Average } \\
\text { Precipitation } \\
\text { Yearly (mm) }\end{array}$ & $\begin{array}{c}\text { Average } \\
\text { Annual } \\
\text { Temperature } \\
\left({ }^{\circ} \mathbf{C}\right)\end{array}$ & Rainy Season \\
\hline Aracaju & 174.053 & 648.939 & 1.409 & 25.6 & March to \\
São Cristóvão & 437.437 & 89.027 & 1.779 & 25.2 & August \\
Nossa Senhora do Socorro & 157.515 & 181.503 & 1.509 & 25.2 & 25.4 \\
Itaporanga d'Ajuda & 757.283 & 33.994 & 1.395 & 25.6 & \\
Barra dos Coqueiros & 91.101 & 29.873 & 1.417 & & \\
\hline
\end{tabular}

*estimativa IBGE 2018 
field data sheet was filled in with data referring to the characteristics of the environment (presence of garbage, sewage, vegetation, among others).

For the identification of A. fulica, the typical characteristics of the shell were observed as described by Salgado (2010). The collected mollusks were stored in 50 liter polyethylene boxes and transported to the laboratory where they were kept and fed with fresh leaves of lettuce three times a week.

\subsection{Biometry, analysis of mucus and fecal material}

All collected mollusks were measured following size distribution according to Fischer; Colley (2005) and Almeida (2013): very young (up to $1.0 \mathrm{~cm}$ ), young (between $1.01 \mathrm{~cm}$ and $4.0 \mathrm{~cm})$, young adults $(4.01$ to $7.0 \mathrm{~cm})$ and adults (greater than $7.01 \mathrm{~cm}$ ).

The mucus used for analysis was obtained by manual stimulation of the foot gland in Petri dishes of each mollusk separately and later placed on a slide for microscopic analysis (Pieruzzi, 2012).

The fecal material of each mollusk collected was processed following the methodology of spontaneous sedimentation (Chaves et al., 1979), using feces that were homogenized with water and transferred to a $100 \mathrm{ml}$ settling cup through a specific filter, for further microscopic analysis.

\subsection{Identification of nematodes}

The identification and preparation of the slides followed the methodology described by Thiengo and Fernandez (2010). The parasites collected in the mucus and feces of $A$. fulica were fixed and stored in alcohol $70 \%$ and later clarified in lactophenol for observation of their internal organs. Illustrations were made using a coupled light camera microscope to aid in identification to the lowest possible taxonomic level. The identification of the nematodes found was performed using the taxonomic key (Anderson et al., 1982).

Larvae of nematodes collected were analyzed at the Oswaldo Cruz Foundation - Laboratory of Helminthology and Medical Malacology, Rio de Janeiro. The larvae were submitted to DNA extraction for PCR-RFLP. The profile obtained was compared to the profile of $A$. cantonensis or A. costaricensis (Caldeira et al., 2003).

\subsection{Weather data}

Monthly averages of temperature, humidity and precipitation were obtained from the National Institute of Meteorology (INMET).

\subsection{Statistical analysis}

The database was tabulated in Microsoft Excel software version 2016. The frequency, length and width averages of A. fulica and the nematode positivity rate were compared with environmental variables such as rainfall and humidity. The minimum and maximum temperature averages were evaluated during the sample collection period and the differences between sample size and nematode positivity were analyzed by the Fisher exact test. In order to associate the presence of garbage with the frequency of $A$. fulica, the Qui-Square Equality test was used. The D'agostino and Pearson and Kolmogorov-Smirnov tests were used to demonstrate the parametric or non-parametric distribution of the data. The statistical differences between the groups were determined by the $\mathrm{T}$ and Mann-Whitney tests. The correlation between the data of the samples and the environmental variables was performed by the Spearman correlation test. Analyzes were performed using Graph Pad Prism version 5.0 software. The results were considered statistically significant when a value of $\mathrm{p}<0.05$ was obtained.

\section{Results}

\subsection{Quantitative and size of collected mollusks}

Specimens of A. fulica were found in the five cities investigated. Most of the mollusks were collected in São Cristóvão and Nossa Senhora do Socorro, 31.3\% and $35.5 \%$, respectively, out of a total of 1,268 specimens. The length of the mollusks ranged from $1.36 \mathrm{~cm}$ to $10.2 \mathrm{~cm}$, with a mean of $5.11 \mathrm{~cm}$ (standard deviation 1.29), 72.6\% of the mollusks were considered young adults $(4-7 \mathrm{~cm})$. The largest number of mollusks was observed in plot I in Aracaju, São Cristóvão and Barra dos Coqueiros, while in Nossa Senhora do Socorro and Itaporanga

Table 2. Achatina fulica distribution in the period from june 2016 to may 2017, in the plots of the cities surveyed in the Great Aracaju Territory, Sergipe, Brazil.

\begin{tabular}{lcccc}
\hline \multicolumn{1}{c}{ Municipalities } & $\begin{array}{c}\text { Plots I } \\
\mathbf{n}(\mathbf{\%})\end{array}$ & $\begin{array}{c}\text { Plots II } \\
\mathbf{n}(\boldsymbol{\%})\end{array}$ & $\begin{array}{c}\text { Plots III } \\
\text { n (\%) }\end{array}$ & Total \\
\hline Aracaju & $218(99.0)$ & $2(1.0)$ & $0(0)$ & 220 \\
São Cristovão & $278(70.0)$ & $106(26.7)$ & $13(3.3)$ & 397 \\
Itaporanga d'Ajuda & $34(54)$ & $15(9.4)$ & $90(56.6)$ & 139 \\
Nossa Senhora do Socorro & $145(32.2)$ & $105(23.3)$ & $200(44.5)$ & 450 \\
Barra dos Coqueiros & $39(92.9)$ & $3(7.1)$ & $0(0)$ & 42 \\
\hline
\end{tabular}


d'Ajuda, a greater amount of mollusks were found in plot III (Table 2).

\subsection{Environmental conditions and presence of mollusks}

Mollusks were collected in the five cities in the plots with the presence of garbage at some point during the study period, in waste lands with nearby houses, unfinished buildings and places with unrealized maintenance of the environment. A. fulica has also been found on stone walls and bricks that serve as shelter and which are also the linear boundaries between houses near the plots.

In the 180 samples collected at the beginning of the study period, the presence of $A$. fulica in the areas with presence of garbage was observed in $72.34 \%$ of the collections. On the other hand, in $66.28 \%$ of the collections in which garbage was not observed in the plots, there was also no presence of the mollusk. It was identified that the samples with the presence of garbage influence the increase
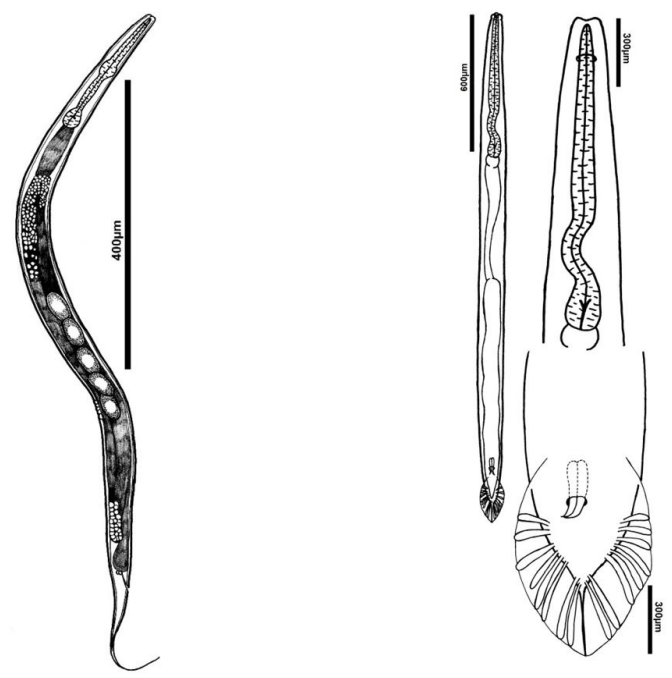

A

Figure 1. (A) Female nematode of the genus Rhabditis isolated from mucus and faeces of Achatina fulica collected at cities in the Great Aracaju Territory, Sergipe, Brazil. (B) Male nematode of the genus Rhabditis, isolated from the mucus and Achatina fulica faeces collected in neighborhoods of the cities of Aracaju, Sergipe, Brazil. Source: Illustration elaborated by André Mota. of the frequency of $A$. fulica, demonstrating a significant statistical difference $(\mathrm{p}=0.0001)$.

\subsection{Infection of A. fulica by nematodes}

When evaluated the mucus and faeces of the mollusks, nematodes of the genus Rhabtidis (Figure 1) were observed in $19.3 \%$ (245) of the A. fulica specimens. Mollusks from the city of São Cristóvão presented the highest frequency of nematodes of the genus Rhabditis (30.9\%) (Table 3). Male and female specimens of the genus Rhabditis were collected.

On the other hand, the analysis of the molecular profile of the isolated larvae showed that these did not correspond to larvae of Angiostrongylus cantonensis or Angiostrongylus costaricensis.

\subsection{Achatina fulica and rainfall}

Throughout the study period, including drought and rainy periods, there were oscillations in the number of A. fulica specimens collected. Aracaju reached its highest peak in November 2016. In the municipality of São Cristóvão the quantity of mollusks collected was higher in August 2016. In Nossa Senhora de Socorro, the largest number of mollusks collected was in January of 2017 with absence of mollusks in the following month. In Itaporanga d'Ajuda the largest number of mollusks collected was in August 2016. In the Barra dos Coqueiros, there were no mollusks in the months of April and May 2017 (Figure 2).

The influence of rain on the frequency of A. fulica showed a significant correlation $(\mathrm{p}=0.01)$, in this way the higher the rainfall, the greater the chances of the presence of the African giant mollusk. On the other hand, no significant correlation was observed between rainfall and mollusk length, as well as between rainfall and the presence of nematodes (Figure 3).

When evaluating the relationship between humidity and the frequency of $A$. fulica, it was observed that there was a significant correlation $(\mathrm{p}=0.0001)$, which shows that the higher the humidity of the air the greater the number of mollusks collected (Figure 4). In the same way humidity interferes with the presence of nematodes in mollusks $(\mathrm{p}=0.02)$. There was no significant correlation between humidity and mollusk length (Figure 5).

Table 3. A. fulica examined in the Great Aracaju Territory, Sergipe, Brazil, infected by Rhabditis sp.

\begin{tabular}{lccc}
\hline \multicolumn{1}{c}{ Counties } & Examined $\mathbf{~ n}$ & Infected n & \% \\
\hline \multicolumn{1}{c}{ Aracaju } & $\mathbf{2 2 0}$ & $\mathbf{3 9}$ & $\mathbf{1 7 . 7}$ \\
São Cristovão & 397 & 123 & 30.9 \\
Itaporanga d'Ajuda & 159 & 22 & 13.8 \\
Nossa Senhora do Socorro & 450 & 61 & 13.5 \\
Barra dos Coqueiros & 42 & 0 & 0 \\
Total & 1.268 & 245 & $19.2 \%$ \\
\hline
\end{tabular}




\subsection{Length of A. fulica and presence of nematodes}

The results concerning the length of the shell show that the bigger the size of the mollusk larger are the chances of them being positive for nematodes $(\mathrm{p}<0.0001)$. Regarding the size classes of $A$. fulica, it was identified that there was a higher percentage of young adult mollusks $(4.01$ to $7.0 \mathrm{~cm})$ and adults $(>7.01 \mathrm{~cm})$, mollusks smaller than $1 \mathrm{~cm}$ were not found the study period. The presence of nematodes was significantly higher in mollusks above $4 \mathrm{~cm}(\mathrm{p}<0.0001)$.
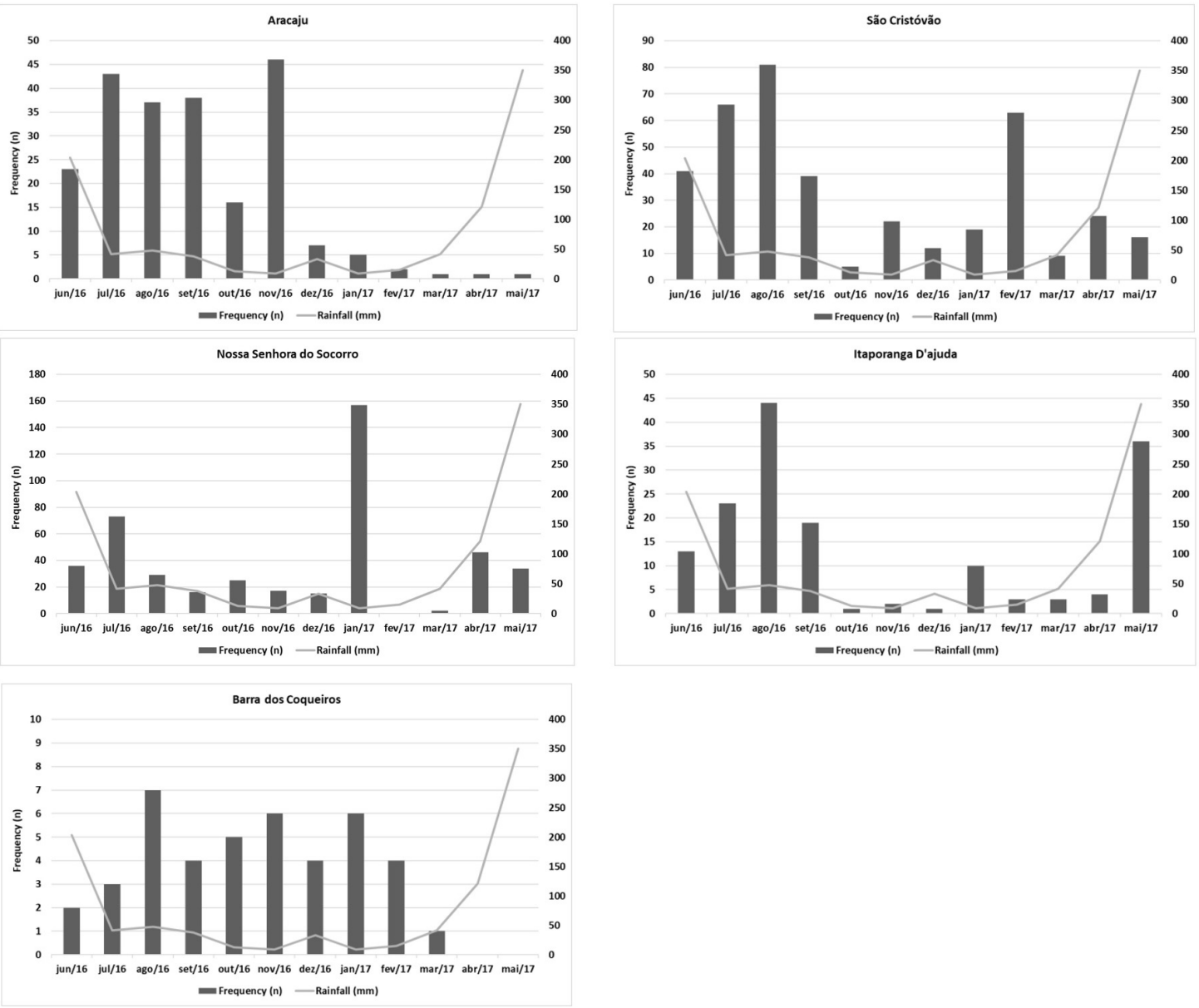

Figure 2. Frequency of A. fulica and rainfall accumulated monthly between june 2016 and may 2017 in the cities of Aracaju, São Cristovão, Nossa Senhora de Socorro, Itaporanga d'Ajuda and Barra dos Coqueiros, Sergipe, Brazil.
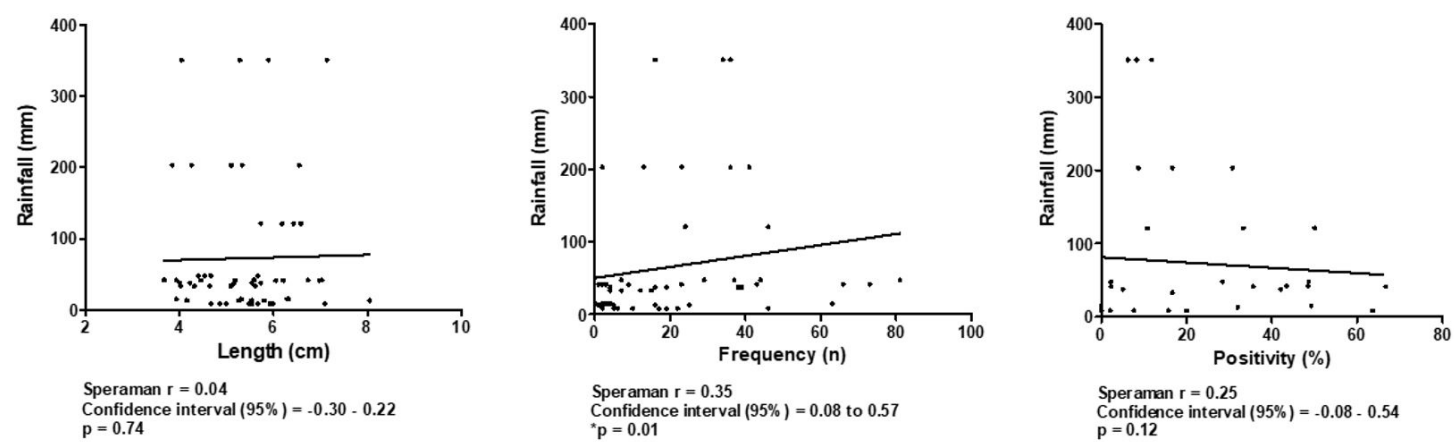

Figure 3. Correlation between rainfall and length (cm), frequency (n) and positivity (\%) of $A$. fulica between june 2016 and may 2017 in the cities of Aracaju, Barra dos Coqueiros, São Cristovão, Itaporanga d'Ajuda and Nossa Senhora do Socorro, Sergipe, Brazil. 

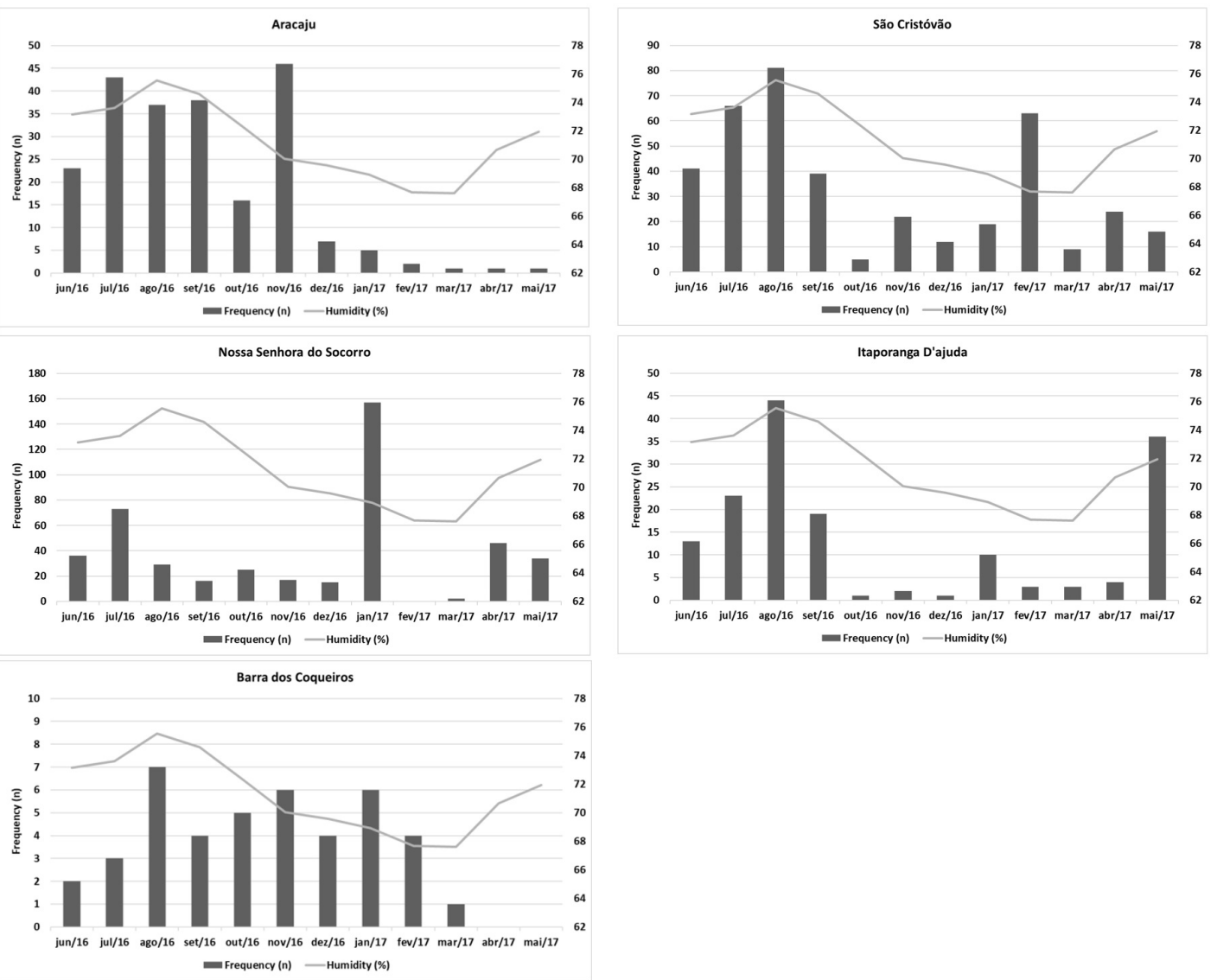

Figure 4. Frequency of A. fulica and relative humidity monthly between june 2016 and may 2017 in the city of Aracaju, São Cristovão, Nossa Senhora de Socorro, Itaporanga d'Ajuda and Barra dos Coqueiros, Sergipe, Brazil.
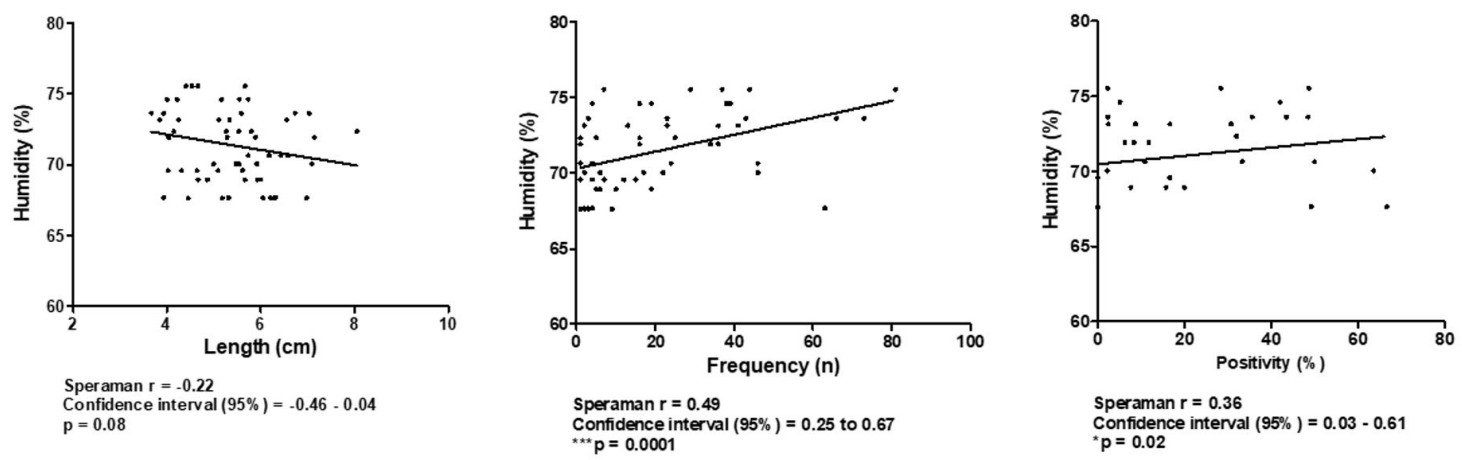

Figure 5. Correlation between the relative air humidity (\%) and the length (cm), frequency (n) and positivity (\%) of $A$. fulica between june 2016 and may 2017 in the cities of Aracaju, Barra dos Coqueiros, São Cristovão, Itaporanga d'Ajuda and Nossa Senhora do Socorro, Sergipe, Brazil.

\section{Discussion}

During the study period it was observed that the plots had similar characteristics, always close to the residences, places with garbage, waste lands with no maintenance, open sewers in some plots, with vegetation and shrubs, debris and unfinished constructions. In the places where these characteristics were added, the largest number of $A$. fulica specimens were collected, probably due to the solid waste being used as shelter, as well as the lack of cleanness of the waste lands, favoring the proliferation and maintenance of the species. These observations have already been reported by other authors, such as Albuquerque et al. (2008) in Lauro de Freitas, Bahia, who observed A. fulica in waste lands near houses, inside stone walls, debris and gardens. 
The presence of garbage in the plots directly influences the presence of $A$. fulica, since the odds ratio of finding the African giant mollusk is five times greater $(\mathrm{OR}=5.14)$ when compared to plots where there is no garbage. The results of this research corroborate the study of Oliveira et al. (2013), which identified the presence of $A$. fulica in three districts of the city Feira de Santana, Bahia in plots with presence of organic garbage, debris and leaves fallen from the trees on the place. Albuquerque et al. (2008), in the city of Lauro de Freitas/BA, 1,274 specimens of $A$. fulica were collected before deforestation and cleaning of the trash were carried out; after cleaning the area the population of mollusks reduced to 378 . In this way, we can show that the anthropic action can be an important regulator of the population of $A$. fulica, influencing the increase or reduction of the number of mollusks in the environment.

The lower amount of garbage and sandy soil, characteristic of the three plots of the municipality of Barra dos Coqueiros, may have influenced the smallest number of $A$. fulica specimens collected; the mollusks have always been observed near trash and around coconut palms typical of the region. Fischer (2009) observed that hatching of giant African mollusk eggs occurs on all substrates that remain moist, but the best type of soil for A. fulica proliferation is wet land that allows 55\% success of hatching of eggs, on the other hand in the sea sand the hatching can be less than 5\%. Barra dos Coqueiros, due its location, suffers a great influence of the sea, which could explain the smaller number of mollusks in the area.

In São Cristóvão, 397 mollusks were found in plots that presented garbage, unfinished constructions that served as hiding places for mollusks, mainly inside bricks and near the linear limits of the lots, under rocks and sheltered in the vegetation that was present throughout the period of study.

In Nossa Senhora de Socorro, 450 specimens of $A$. fulica were collected, which were found mainly under rubbish. In this city, one of the parcels served as an irregular garbage and debris deposit, used by the local community. This may be the reason why in january 2017 the largest quantity of mollusks was collected, even though it was the dry season. In the month of february of the same year no live mollusks were found, only empty shells of A. fulica. During this period, the local community carried out maintenance of some areas, including the research plots, removing all trash, debris and vegetation, which may be the reason why in february no mollusks were found.

Achatina fulica uses a wide variety of residues as food source, which are present mainly in anthropic environment, favoring the proliferation, maintenance and dissemination of the African giant mollusk. The presence of foliage, garbage and other wastes serve as protection and provide food sources, consequently in environments with these characteristics it is possible to find these mollusks and in greater quantity (Fischer and Amadigi, 2010; Santos and Delabie, 2011). The human occupation has been associated to the presence of African giant mollusks, thus, cities with extensive urban areas have a greater presence of the mollusk, mainly in areas with no maintenance that favor the disordered growth of plants, garbage accumulation and debris. The increasing number of mollusks in waste lands may still be related to the strong presence of organic matter that represents an important food source for $A$. fulica (Fischer et al., 2010).

In Brazil the first record of Rhabdits sp. in A. fulica was in Goiás, other records were already made in seven cities in the state of Rio de Janeiro (Bom Jesus de Itabapoana, Barra do Piraí, Duque de Caxias, Niterói, Rio de Janeiro, São Gonçalo and Valença (Oliveira et al., 2010; Zanol et al., 2010). The parcels with the largest number of mollusks in which the presence of Rhabditis sp. were located in the cities of São Cristóvão and Nossa Senhora do Socorro. These were the places that had the parcels with the largest amount of garbage and decomposing organic matter. Nematodes of the genus Rhabditis are free-living and may be naturally found in humid places with decaying organic matter (Campos et al., 2002).

In the northeast, Almeida (2014) also reported the presence of the nematode Rhabditis sp. in A. fulica collected in Feira de Santana/BA, in areas with vegetal cover, garbage, sewage and with the presence of domestic animals. The discharge of wastewater into the environment, as a result of the absence of basic sanitation, allows the soil to become humid even during periods of drought, which facilitates the growth and maintenance of the vegetation cover making the places suitable for the presence of both mollusks and of free-living nematodes.

Rhabditis nematodes were found in the faeces of a child with abdominal disorders, in the state of Goiás, Brazil (Campos et al., 2002). The possibility of the presence of nematodes in humans can be considered when there is manipulation of the environment and subsequent contamination, once the species is free life and the mollusks can serve as carriers of these nematodes (Anderson et al., 1982). It is important to emphasize the difficulty of specific diagnosis within the genus Rhabditis as well as the similarity with larvae of other genera such as Strongyloides (Oliveira et al., 2010).

According to Silva et al. (2013), Rhabditis sp when being carried by A. fulica can contaminate food. In Anápolis, Goiás, there was the first record of the presence of nematodes of the genus Rhabditis in lettuce (Lactuva sativa); of 150 lettuce samples, the nematode was found in 7. Campos et al. (2009) in the State of Goiás, Brazil, reported the occurrence of Rhabditis sp. in cattle of the Gir breed, the ear, head and auricular shapes favor the retention of earwax associated with the presence of hairs, secretions, heat and humidity, providing an ideal environment for the development of Rhabditis $\mathrm{sp}$. which can lead to bovine otitis. It is evident that nematodes of the genus Rhabditis are able to use other environments for their development, which may explain the association of this nematode with A. fulica, the latter providing shelter in its own shell.

It was observed in this research that even in the dry season with low rainfall rates, the African giant mollusk was present. This fact may be related to the mollusk defense system that uses behaviors such as the formation of 
epiphany that allows the mollusk to survive even with low humidity (Simião and Fischer, 2004). Sarma et al. (2015), observed that higher temperatures and low rainfall were the main climatic variables that contributed to the reduction of A. fulica and invasions of new areas. According to Cook (2001), the mollusk loses water through the integument, but also rehydrates by the contact between the integument and the environment in which A. fulica is inserted. Among some behavioral strategies that guarantee the survival of A. fulica in periods with low rainfall, this is also due to the retreatment of the cephalopodial mass into the shell and soil burial (Almeida, 2013; Taofiq et al., 2017).

For a good part of the study period, the quantitative mollusks accompanied the increase of the relative humidity of the air, this parameter remained high even with low rainfall rates, a characteristic of the climate of the coastal area of Northeastern Brazil. It may have been the factor that favored the survival of the A. fulica species in the dry periods in some of the places investigated. Despite the decline in humidity, there was a mollusk peak in the municipalities of Aracaju (November), Nossa Senhora de Socorro (january) and São Cristóvão (february), this peak may be related to the greater amount of garbage and debris accumulated in the plots in these months. According to Raut and Barker, (2002) and Costa (2010), A. fulica, like other terrestrial mollusks, require humid environments, always looking for locations beneath the trunks, leaves and other objects present in the medium. In a way the temperature, the relative humidity of the air and the humidity of the substrate contribute to the activity of the terrestrial mollusks. Onyshi et al. (2018), report in Nigeria that climatic conditions, especially high humidity and the rainy season are factors that favor the increase of the population of A. fulica.

Albuquerque et al. (2009) identified humidity as the main climatic variable that influenced the length and total weight of A. fulica. Takeda and Ozaki (1986) demonstrated an endogenous circadian rhythm in the activity of A. fulica, this characteristic would be independent of the temperature and light conditions, but regulated by hydration effects. In addition, these authors showed that the African giant mollusk only becomes active when the humidity is above $50 \%$.

We identified that mollusks of greater length were more frequently associated with the presence of Rhabditis, probably due to their longer exposure to the environment and their locomotion activity at the places investigated. Franco-Acuña et al. (2009) identified in his research a strong correlation between the length of A. fulica and the presence of nematodes, showing that mollusks with length between 5.6 and $10 \mathrm{~cm}$ showed a higher frequency of positivity for Rhabditis. The study by Oliveira and Santos (2018) showed that mollusks larger than $9.0 \mathrm{~cm}$ had a higher frequency of nematodes than smaller mollusks.

Almeida (2014) observed that larger mollusks are more wandering, with a longer time of exposure to nematodes, showing that the collection site and mollusk size are variables that directly interfere in the nematode encounter. Moreira et al., (2013), affirm that $A$. fulica due to its characteristic wandering mollusk is more prone to infection by nematodes, as for example A. cantonensis, as reported in the state of Pará. On the other hand, the African giant mollusk has a high reproduction rate and capacity of man-made dispersion, which makes the mollusk more vulnerable to natural infection by nematodes (Córdoba-R et al., 2017).

Fischer and Amadigi (2010) and Raut and Barker (2002) identified in their studies that newly hatched individuals of A. fulica are sedentary and feed on eggshells and decaying plant material, and youngsters begin to be dispersive feeding on green leaves, while adults are territorial and exhibit a more erratic behavior by feeding mainly on decomposing material. These behaviors of the different phases of life of A. fulica would explain the fact that the larger mollusks present with more frequency nematodes of the genus Rhabditis.

We can conclude that $A$. fulica, even with unfavorable climatic conditions, has been successfully maintained in the Great Aracaju Territory. This can be explained by the conditions of the urban environment in which anthropic actions favor the proliferation and maintenance of the species. Free-living nematodes of the genus Rhabditis were found associated to A. fulica in the studied cities, except in Barra dos Coqueiros, being this the only place with the absence of organic garbage. It was identified that in areas with presence of garbage are five times more likely to find mollusks A. fulica. A significant relationship was found between rainfall and the frequency of the African giant mollusk, with a larger number of mollusks being identified in periods of higher rainfall. As for moisture, there was a significant relationship with the frequency of $A$. fulica and the positivity for nematodes of the genus Rhabditis. Regarding humidity, this influence in the presence of $A$. fulica and nematodes of the genus Rhabditis, at the same time that a significant relation between the size of the mollusks and the presence of nematodes was identified. Further studies are recommended since the African giant mollusk is an invasive species that occurs in 25 of the 26 Brazilian states, with different environmental characteristics that may influence the different biological aspects that may also influence the malacological control of the species.

\section{Referências}

ALBUQUERQUE, F.S., PESO-AGUIAR, M.C., ASSUNÇÃOALBUQUERQUE, M.J.T. and GALVEZ, L., 2008. Distribution, feeding behavior and control strategies of the exotic land snail Achatina fulica (Gastropoda: Pulmonata) in the northeast of Brazil. Brazilian Journal of Biology $=$ Revista Brasileira de Biologia, vol. 68, no. 4, pp. 837-842. http://dx.doi.org/10.1590/ S1519-69842008000400020. PMid:19197503.

ALBUQUERQUE, F.S., PESO-AGUIAR, M.C., ASSUNÇÃOALBUQUERQUE, M.J.T. and GALVEZ, L., 2009. Do climate variables and human density affect Achatina fulica (Bowditch) (Gastropoda: Pulmonata) shell length, total weight and condition factor? Brazilian Journal of Biology $=$ Revista Brasileira de 
Biologia, vol. 69, no. 3, pp. 879-885. http://dx.doi.org/10.1590/ S1519-69842009000400016. PMid:19802448.

ALMEIDA, M.N., 2013. Abundância, sazonalidade, reprodução e crescimento da concha de uma população de Achatina fulica (Bowdich, 1822) (Mollusca, Achatinidae) em ambiente urbano. Arquivos de Ciências Veterinárias e Zoologia da UNIPAR, vol. 16 , no. 1 , pp. 51-60.

ALMEIDA, P.H.A. 2014. Avaliação da presença de Achatina fulica Bowdich, 1822(Gastropoda pulmonata) em Feira de Santana, Bahia e estudos de parasitos associados. Feira de Santana: Universidade Estadual de Feira de Santana, 113 p. Dissertação de Mestrado em Zoologia.

ANDERSON, R.C., CHABAUD, A.G. and WILLMOTT, S. 1982. Cih keys to the nematode parasites of vertebrates. In: ANDERSON, R.C. and BAIN, O. Keys to genera of the superfamilies rhabditoidea, dioctophymatoidea, trichinelloidea and muspiceoidea. Inglaterra: Commonwealth Agricultural Bureaux, pp. 396-422.

BOAVENTURA, M.F.F., THIENGO, S.C. and MONTEIRO, S., 2011. Infecções por caramujo africano (Achatina fulica): análise de conteúdo das matérias jornalísticas e de materiais educativos sobre o tema no Rio de Janeiro, Brasil. Revista Brasileira de Pesquisa em Ciências, vol. 11, no. 2, pp. 9-24.

CALDEIRA, R.L., CARVALHO, O.S., MENDONÇA, C.L., GRAEFF-TEIXEIRA, C., SILVA, M.C., BEN, R., MAURER, R., LIMA, W.S. and LENZI, H.L., 2003. Molecular differentiation of Angiostrongylus costaricensis, A. cantonensis, and A. vasorum by polymerase chain reaction restriction fragment length polymorphism. Memorias do Instituto Oswaldo Cruz, vol. 98, no. 8, pp. 10391043. http://dx.doi.org/10.1590/S0074-02762003000800011. PMid:15049087.

CALDEIRA, R.L., MENDONÇA, C.L.G.F., GOVEIA, C.O., LENZI, H.L., GRAEFF-TEIXEIRA, C., LIMA, W.S., MOTA, E.M., PECORA, I.L., MEDEIROS, A.M. and CARVALHO, O.S., 2007. First record of molluscs naturally infected with Angiostrongylus cantonensis (Chen,1935) (Nematoda: Metastrongylidae) in Brazil. Memorias do Instituto Oswaldo Cruz, vol. 102, no. 7, pp. 887-889. http://dx.doi.org/10.1590/S0074-02762007000700018. PMid:18094889.

CAMPOS, D.M.B., ARAUJO, J.L.B., VIEIRA, M.C.M., DAMASCENO, F. and BARBOSA, A.P., 2002. Um caso de parasitismo por Rhabdits sp. em criança natural de Goiânia, Goiás, Brasil. Revista da Sociedade Brasileira de Medicina Tropical, vol. 35, no. 5, pp. 519-522. http://dx.doi.org/10.1590/ S0037-86822002000500016. PMid:12621674.

CAMPOS, S.B.S., SERODIO, J.J., BRAZIL, D.S., SILVA, T.V., PRADO, T.D., MOURA, V.M.B.D. and SILVA, L.A.F. 2009. Evolução clínica, diagnóstico, tratamento e achados de necropsia da otite parasitária por Rhabditis sp. em touro da raça gir - relato de caso. In: VIII Congresso Brasileiro de Buiatria. 21-24 Outubro 2009, Belo Horizonte, Brasil. Goiânia: Ciência Animal Brasileira, suppl. 1, pp. 677-683.

CHAVES, A., ALCANTARA, O.S., CARVALHO, O.S. and SANTOS, J.S., 1979. Estudo comparativo dos métodos coprológicos de Lutz, Kato-katz e Faust modificado. Revista de Saude Publica, vol. 13, no. 1, pp. 348-352. http://dx.doi.org/10.1590/S003489101979000400010. PMid:549225.

COLLEY, E. 2010. Medidas de controle de Achatina fulica. In: FISCHER, M.L.; COSTA, L.C.M. O caramujo gigante africano: Achatina fulica no Brasil. Curitiba: Champagnat, pp. 203-228.

CÓRDOBA-R, D.; PATIÑO-MONTOYA, A.; GIRALDO, A.; 2017. Prevalence of strongylida nematodes associated with african snail, Achatina fulica, in Valle del Cauca, Colombia. Revista Mvz Cordoba, vol. 22, no. 3, pp. 6276-6286. http://dx.doi. org/10.21897/rmvz.1132.

COSTA, L.C.M. 2010. Ecologia de Achatina fulica. In: FISCHER, M.L.; COSTA, L.C.M. O caramujo gigante africano: Achatina fulica no Brasil. Curitiba: Champagnat, pp. 141-174.

COOK, A. 2001. Behavioural ecology: on doing the right thing, in the right place at the right time. In: BARKER, G.M. The biology of terrestrial mollusks. Trowbridge: CABI, pp. 447-487. http:// dx.doi.org/10.1079/9780851993188.0447.

ESTON, M.R., MENEZES, G.V., ANTUNES, A.Z., SANTOS, A.S.R. and SANTOS, A.M.R., 2006. Espécie invasora em Unidade de Conservação: Achatina fulica (Bowdich, 1822) no Parque Estadual Carlos Botelho, Sete Barras, SP. Brasil (Nota Científica). Revista do Instituto Florestal, vol. 18, no. 1, pp. 173-179.

FISCHER, M.L., 2009. Reações da espécie invasora Achatina fulica (Mollusca: Achatininidae) à fatores abióticos: perspectivas para o manejo. Revista de Zoologia, vol. 26, no. 3, pp. 379-385. http://dx.doi.org/10.1590/S1984-46702009005000006.

FISCHER, M.L. and AMADIGI, I.S.N. 2010. Medidas de controle de Achatina fulica. In: FISCHER, M.L.; COSTA, L.C.M. O caramujo gigante africano: Achatina fulica no Brasil. Curitiba: Champagnat, pp. 48-99.

FISCHER, M.L. and COLLEY, E., 2005. Espécie Invasora em Reservas Naturais: Caracterização da População de Achatina fulica Bowdich, 1822 (Molusca-Achatinidade) na Ilha Rasa, Guaraqueçaba, Paraná, Brasil. Revista de Biologia Neotropical, vol. 5, no. 1, pp. 2-18. http://dx.doi.org/10.1590/S1676-06032005000100014.

FISCHER, M.L., COLLEY, E., AMADGI, I.S.N. and SIMIÃO, M.S. 2010. Ecologia de Achatina fulica. In: FISCHER, M.L.; COSTA, L.C.M. O caramujo gigante africano: Achatina fulica no Brasil. Curitiba: Champagnat, pp. 101-140.

FISCHER, M.L., SIMIÃO, M., COLLEY, E., ZENNI, R.D., SILVA, D.A.T. and LATOSKI, N., 2006. O caramujo exótico invasor na vegetação nativa em Morretes, PR: diagnóstico da população de Achatina fulica Bowdich, $1822 \mathrm{em}$ um fragmento de floresta ombrófila densa aluvial. Biota Neotropica, vol. 6, no. 2, pp. 1-5. http://dx.doi.org/10.1590/S1676-06032006000200029.

FRANCO-ACUÑA, D.O., PINHEIRO, J., TORRES, E.J., LANFREDI, R.M. and BRANDOLINI, S.V., 2009. Nematode cysts and larvae found in Achatina fulica Bowdich, 1822. Journal of Invertebrate Pathology, vol. 100, no. 2, pp. 106-110. http:// dx.doi.org/10.1016/j.jip.2008.11.008. PMid:19061895.

GRAEFF-TEIXEIRA, C., SILVA, A.C. and YOSHIMURA, K., 2009. Update on eosinophilic meningo encephalitis and its clinical relevance. Clinical Microbiology Reviews, vol. 22, no. 2, pp. 322-348. http://dx.doi.org/10.1128/CMR.00044-08. PMid:19366917.

LIMA, M.S. and GUILHERME, E., 2018. Diagnosis, presence of endoparasites, and local knowledge on the infestation of the exotic giant african snail (gastropoda: pulmonata: achatinidae), in the urban zone of Rio Branco, Acre, Brazil. Biota Neotropica, vol. 18, no. 3, pp. 1-10. http://dx.doi.org/10.1590/1676-0611bn-2017-0503.

MOREIRA, V.L.C., GIESE, E.G., SIMOES, R.O., THIENGO, S.C., MALDONADO JUNIOR, A. and SANTOS, J.N., 2013. Endemic angiostrongyliasis in the Brazilian Amazon: Natural parasitism of Angiostrongylus cantonensis in Rattus rattus and $R$. norvegicus, and sympatric giant African land snails, Achatina 
fulica. Acta Tropica, vol. 125, no. 1, pp. 90-97. http://dx.doi. org/10.1016/j.actatropica.2012.10.001. PMid:23072946.

OHLWEILER, F.P., GUIMARÃES, M.C.A., TAKAHASHI, F.Y. and EDUARDO, J.M., 2010. Current distribution of Achatina fulica, in the state of São Paulo including records of Aelurostrongylus abstrusus (nematoda) larvae infestation. Revista do Instituto de Medicina Tropical de São Paulo, vol. 52, no. 4, pp. 211-214. http://dx.doi.org/10.1590/S0036-46652010000400009. PMid:21748230.

OLIVEIRA, D.S., JERALDO, V.L.S. and MELO, C.M. 2007. Estudo de populações urbanas de Achatina fulica no estado de Sergipe, Brasil. In: Anais do VIII Congresso de Ecologia do Brasil, Setembro 2007, Caxambu, Brasil: Sociedade Brasileira de Ecologia do Brasil, pp. 1-2.

OLIVEIRA, J.L; SANTOS, S.B., 2018. Distribution of cysts of Strongyluris sp. (Nematoda) in the pallial system of Achatina fulica Bowdich, 1822 from Vila Dois Rios and Vila do Abraão, Ilha Grande, Angra dos Reis, Rio de Janeiro. Brazilian Journal of Biology, vol. 79, no. 1, pp. 1-7.

OLIVEIRA, A.P.M., TORRES, E.J.L., MALDONADO-JUNIOR, A., ARAUJO, J.L.B., FERNANDEZ, M.A. and THIENGO, S.C., 2010. Achatina fulica como hospedeiro intermediário de nematódeos de interesse médico-veterinário em Goiás, Brasil. Revista de Patologia Tropical, vol. 39, no. 3, pp. 199-210.

OLIVEIRA, J.C.S., CORRÊA, K.J.G. and VASCONCELOS, H.C.G., 2013. Ocorrência de Achatina fulica (Molusca: Pulmonata: Achatinidae) em três bairros da cidade de Santana, Amapá. Biota Amazônia, vol. 3, no. 1, pp. 9-12. http://dx.doi.org/10.18561/21795746/biotaamazonia.v3n1p9-12.

ONYSHI, G.C., AGUZIE, I.O., OKORO, J.O., NWANI, C.D., EZENWAJI, N., OLUAH, N.S. and OKAFOR, F.C., 2018. Terrestrial snail fauna and associated helminth parasites in a tropical semi-urban zone, Enugu state, Nigeria. Pakistan Journal of Zoology, vol. 50, no. 3, pp. 1079-1085. http://dx.doi. org/10.17582/journal.pjz/2018.50.3.1079.1085.

PIERUZZI, P.A.P. 2012. Estudo da determinação da concentração inibitória mínima do muco de Achatina fulica sobre Staphylococcus áureos ATCC 25923. Pirassununga: Faculdade de Medicina Veterinária e Zootecnia da Universidade de São Paulo, 55 p. Dissertação de mestrado em Nutrição e Produção animal.

RAUT, S.K. and BARKER, G.M. 2002. Achatina fulica Bowdich and others achatinidae pest in tropical agriculture. In: BARKER, G.M. Molluscs as crop pests. In. New Zealand: CAB Publishing, pp. 55-114. http://dx.doi.org/10.1079/9780851993201.0055.

SARMA, R.R., MUNSI, M. and ANANTHRAM, A.N., 2015. Effect of Climate Change on Invasion Risk of Giant African Snail (Achatina fulica Férussac, 1821: Achatinidae) in India. PLoS One, vol. 10, no. 11, pp. 1-16. PMid:26618637.

SALGADO, N.C. 2010. Morfologia e taxonomia: recaracterização de Achatina (Lissachatina) fulica (Mollusca, Gastropoda, Stylommatophora, Achatinidae. In: FISCHER, M.L. and COSTA, L.C.M. O caramujo gigante africano: Achatina fulica no Brasil. Curitiba: Champagnat, pp. 12-41.

SANTOS, J.R.M. and DELABIE, J.H.C., 2011. Controle natural de Achatina fulica (Mollusca, Gastropoda) por Ocypode quadrata
(Crustacea, Decapoda) em restinga antropizada de Ilhéus, Bahia, Brasil. Sitientibus. Série Ciências Biológicas, vol. 11, no. 1, pp. 94-98. http://dx.doi.org/10.13102/scb144.

SILVA, E.C. and ALELUIA, F.T.F., 2010. Ocorrência de Achatina fulica Bowdich, 1822 (Mollusca, Gastropoda) em Salvador, Bahia, Brasil. Revista Brasileira de Zoociências, vol. 12, no. 2, pp. 199-204.

SILVA, T.C., RODRIGUES, T.P., CARVALHO, P.D., OLIVEIRA, T.B. and CAMPOS, D.M.B., 2013. Encontro de Rhabditis sp. em alface Lactuca sativa comercializada em Anápolis, Goiás, Brasil. Revista de Patologia Tropical, vol. 42, no. 2, pp. 201-207.

SIMIÃO, M.S. and FISCHER, M.L., 2004. Estimativa e inferência do método de controle do molusco exótico Achatina fulica Bowdich 1822 (stylommatophora: achatinidae) em Pontal do Paraná, litoral do estado do Paraná. Cadernos da Biodversidade, vol. 4 , no. 2, pp. 74-83.

TAKEDA, N. and OZAKI, T., 1986. Induction of locomotor behaviour in the giant african snail, Achatina fulica. Revista Comparative Biochemistry and Physiology, vol. 83, no. 1, pp. 77-82. http://dx.doi.org/10.1016/0300-9629(86)90091-5.

TAOFIQ, S., BUNZA, M.D.A., MAJED, Q., ABUBAKAR, M.B. and LADAN, M.U., 2017. Studies on snail vectors of helminth disease agents along rima river valley at Kwalkwalawa village, Wamakko local. SM Tropical Medicine Journal, vol. 2, no. 1, pp. 1-5.

THIENGO, S.C., FARRACO, F.A., SALGADO, N.C., COWIE, R.H. and FERNANDEZ, M.A., 2007. Rapid speed of an invasive snail in south America: The giant african snail, Achatina fulica, in Brasil. Biological Invasions, vol. 9, no. 1, pp. 693-702. http:// dx.doi.org/10.1007/s10530-006-9069-6.

THIENGO, S.C., FERNANDEZ, M.A., TORRES, E.J.L., COELHO, P.M. and LANFREDI, R.M., 2008. First Record of a nematode Metrastrongyloidea (Aelurostronglylus abstrusus larvae) in Achatina (Lissachatina) fulica (Molusca, Achatinadae) in Brasil. Journal of Invertebrate Pathology, vol. 98, no. 1, pp. 34-39. http://dx.doi.org/10.1016/j.jip.2007.10.010. PMid:18078952.

THIENGO, S.C. and FERNANDEZ, M.A. 2010. Achatina fulica: um problema de saúde pública? In: FISCHER, M.L. and COSTA, L.C.M. O caramujo gigante africano: Achatina fulica no Brasil. Curitiba: Champagnat, pp. 189-201.

THIENGO, S.C., SIMÕES, R.O., FERNANDEZ, M.A. and MALDONADO JÚNIOR, A.M., 2013. Angiostrongylus cantonensis and rat lungworm disease in Brazil. Hawai' $i$ Journal of Medicine \& Public Health : a Journal of Asia Pacific Medicine \& Public Health, vol. 72, no. 6, suppl. 2, pp. 18-22. PMid:23901376.

WANG, Q.P.; LAI, D.H.; ZHU, X.Q.; CHEN, X.G.; LUN, Z.R., 2008. Human angiostrongyliasis. Revista Lancent Infectiouns. Diseases (Basel, Switzerland), vol. 8, no. 1, pp. 621-630.

ZANOL, J., FERNANDEZ, M.A., OLIVEIRA, A.P.M., RUSSO, C.A.M. and THIENGO, S.C., 2010. O Caramujo exótico invasor Achatina fulica (Stylommtophora, Mollusca) no estado do Rio de Janeiro (Brasil): situação atual. Biota Neotropica, vol. 10, no. 3, pp. 448-451. http://dx.doi.org/10.1590/S1676-06032010000300038. 